\title{
Implications of compound heterozygous insulin receptor mutations in congenital muscle fibre type disproportion myopathy for the receptor kinase activation
}

\author{
H.H. Klein ${ }^{1}$, R. Müller ${ }^{1}$, H. Vestergaard ${ }^{2}$, O. Pedersen ${ }^{2}$ \\ ${ }^{1}$ Department of Internal Medicine 1, Medizinische Universität zu Lübeck, Lübeck, Germany \\ ${ }^{2}$ Steno Diabetes Center, Copenhagen, Denmark
}

\begin{abstract}
Summary We studied insulin receptor kinase activation in two brothers with congenital muscle fibre type disproportion myopathy and compound heterozygous mutations of the insulin receptor gene, their parents, and their unaffected brother. In the father who has a heterozygote $\mathrm{Arg}^{1174} \rightarrow$ Gln mutation, in situ activation of the receptor kinase in skeletal muscle was reduced about $70 \%$. Selection of only those receptors that bound to anti-phosphotyrosine antibody showed that these receptors had normal kinase activity and that the reduction in overall kinase activity was due to the inability of about $70 \%$ of the receptors to become insulin-dependently activated. The mother carries a point mutation at the last base pair in exon 17 which, due to abnormal alternative splicing, could lead to normally transcribed receptor or truncated receptor lacking the kinase region. Kinase activation was normal in the mother's skeletal
\end{abstract}

muscle, suggesting that virtually no truncated receptor was expressed. Receptor kinase activity was, however, reduced by 95 and $91 \%$ in the compound heterozygous brothers. This suggests that the mother's mutated allele contributes little to the generation of functional receptor protein and that the receptors in the mother's skeletal muscle are transcribed almost exclusively from the non-mutated allele. The mutation in exon 17 could lead to reduced transcription or rapid degradation of a predominantly transcribed truncated gene product or both. [Diabetologia (1999) 42: 245-249]

Keywords Insulin receptor kinase, compound heterozygous insulin receptor mutations, human muscle, erythrocytes, congenital fibre type disproportion myopathy.
Recently we reported the association of severe insulin resistance and congenital fibre type disproportion myopathy (CFTDM) in two brothers from a Danish family [1]. It has now been shown that the insulin resistance and possibly the myopathy in the two broth-

Received: 4 May 1998 and in final revised form:

4 September 1998

Corresponding author: Prof. H.H. Klein, Medizinische Klinik 1, Medizinische Universität zu Lübeck, Ratzeburger Allee 160, D-23538 Lübeck, Germany

Abbreviations: CFTDM, congenital fibre type disproportion myopathy; $\alpha \mathrm{PY}$, anti-phosphotyrosine antibody; $\alpha \mathrm{IR}$, anti-insulin receptor antibody; IRS-1, insulin receptor substrate-1; GLU4:TYR1, Polymer with a 4:1 ratio of glutamic acid and tyrosine, used as insulin receptor substrate; IGF-1, insulin-like growth factor-1. ers is associated with compound heterozygous mutations of the insulin receptor gene [2]. The allele inherited from their father, who is less insulin resistant and has no CFTDM [1], has a missense mutation that changes $\operatorname{Arg}^{1174} \rightarrow$ Gln. The allele inherited from their mother, who is less insulin resistant than the patients and her husband [1], carries a point mutation at the last base pair in exon 17 (position 3396). This G to A change affects the -1 donor splice site of exon 17 , resulting in a mixture of two mRNAs from that allele. The abnormal skipping of exon 17 (exon 17- variant) shifts the amino acid reading frame and creates a stop codon 36 amino acids after the end of the sequence encoded by exon 16 and this leads to a truncated receptor missing the entire tyrosine kinase domain. In the exon 17 + variant, the point mutation is silent and should result in a normally transcribed insulin receptor. 
Here we investigate the relative ratios between functionally intact and kinase defective insulin receptors in the skeletal muscle of the patients' parents. Moreover, we explore in erythrocytes of all family members how the existence of the individual heterozygote mutations and their compound heterozygote coexistence affect insulin-activation of the receptor kinase in these cells.

\section{Subjects and methods}

Subjects. The clinical characteristics of the two brothers with compound heterozygous insulin receptor mutations and CFTDM, their parents and their unaffected brother have been reported [1]. Control subjects for the studies in muscle were the same as in this previous report. Erythrocyte studies were done using other control subjects $(n=4$; age $25 \pm 2$ years, BMI $21.7 \pm 0.7 \mathrm{~kg} / \mathrm{m}^{2}$, fasting plasma glucose $4.4 \pm 0.2 \mathrm{mmol} / \mathrm{l}$, fasting plasma insulin $34 \pm 3 \mathrm{pmol} / \mathrm{l}, \mathrm{HbA}_{1 \mathrm{c}}$ $5.8 \pm 0.1 \%$ ). Before entry into the study, the purpose and risks of the experimental protocol were carefully explained to all of the volunteers and their informed consent was obtained. The protocol was approved by the local ethics Committees and was in accordance with the Helsinki II Declaration.

Euglycaemic hyperinsulinaemic clamps and muscle biopsies. Percutaneous muscle biopsies from the vastus lateralis muscle were obtained at the end of a 2-h basal period and again at the end of a 4-h euglycaemic hyperinsulinaemic clamp period as described [1] and immediately frozen in liquid nitrogen.

Separation of anti-phosphotyrosine antibody-binding and nonanti-phosphotyrosine antibody-binding muscle insulin receptors. Muscle samples were made soluble under conditions designed to preserve the phosphorylation state of the receptors $[1,3]$ and aliquots added to microwells coated with anti-phosphotyrosine antibody $(\alpha \mathrm{PY})$ [4]. After $16 \mathrm{~h}$ at $4{ }^{\circ} \mathrm{C}$, the supernatant (non- $\alpha$ PY-binding fraction) was collected. Proteins bound to the antibody ( $\alpha$ PY-binding fraction) were detached by adding $30 \mu \mathrm{l}$ of buffer containing $100 \mathrm{mmol} / \mathrm{l}$ phenylphosphate as described [4].

Muscle insulin receptor kinase and insulin binding activities. Aliquots of the non- $\alpha \mathrm{PY}$-binding fraction, the $\alpha \mathrm{PY}$-binding fraction and the original solubilized muscle sample (total fraction) were pipetted into separate microwells coated with antiinsulin receptor antibody $(\alpha I R)$-wells $[1,3-5]$. After the receptors had bound to the antibody ( $>90 \%$ of the insulin receptors bind [3]) the wells were washed. Kinase activity was then measured with or without prior in vitro-activation of the receptors as described [4]. Briefly, for in vitro-activation of the receptors, the respective wells were incubated $4 \mathrm{~h}$ at $4{ }^{\circ} \mathrm{C}$ with buffer containing $2 \mathrm{mmol} / \mathrm{l}$ ATP, $0.2 \mu \mathrm{mol} / \mathrm{l}$ insulin, $12 \mathrm{mmol} / \mathrm{l} \mathrm{MgCl}_{2}$, and $5 \mathrm{mmol} / \mathrm{l} \mathrm{MnCl}_{2}$. All wells were then washed and phosphorylation reactions carried out with $0.3 \mu \mathrm{mol} / \mathrm{l}{ }^{32} \mathrm{P}$-ATP $(100-200 \mathrm{Ci} / \mathrm{mmol})$ and $2 \mathrm{mg} / \mathrm{ml}$ GLU4: TYR1 exactly as described [1, 4]. Insulin binding activity (defined as the amount of insulin specifically bound at 8.7 $\mathrm{nmol} / \mathrm{l})$ was measured as described [3-5].

Erythrocyte insulin receptor kinase and binding activities. First $2 \mathrm{ml}$ aliquots of heparinized (final concentration $3.5 \mathrm{U} / \mathrm{ml}$ ) blood were preincubated for $25 \mathrm{~min}$ in a rotary waterbath $\left(37^{\circ} \mathrm{C}, 70 / \mathrm{min}\right)$ and then insulin $(0-400 \mathrm{nmol} / \mathrm{l})$ was added. Af- ter $15 \mathrm{~min}$ the cells were rapidly disrupted in glass tissue grind tubes (Braun, Melsungen, Germany) filled with $1 \mathrm{ml}$ icecold solubilization buffer $[1,3]$. Samples were kept on ice for an additional $20 \mathrm{~min}$, centrifuged at $10^{5} \mathrm{~g}$ for $15 \mathrm{~min}$ to remove insoluble material and stored at $-80^{\circ} \mathrm{C}$. After thawing, samples were twice concentrated by vacuum centrifugation and added to $\alpha$ IR-wells. Insulin receptor kinase and binding activities were measured as described for muscle, except that $2.3 \mu \mathrm{g} / \mathrm{ml}$ recombinant insulin receptor substrate-1 (IRS-1) (Upstate Biotechnology Incorporated, New York, N.Y., USA) was used as substrate. Experiments with leucocyte filtres (PallNewquay, Cornwall, UK) showed that removal of the leucocytes did not alter the measured binding or kinase activities per erythrocyte, indicating that the contribution of the leucocytes to measured kinase and binding activities was negligible (data not shown). The results therefore reflect almost exclusively erythrocyte receptor binding and kinase activities.

\section{Results}

Effect of serum insulin concentration on the fraction of $\alpha P Y$-binding muscle insulin receptors. In the control subjects an increase in steady state serum insulin concentration from $44 \pm 8$ to $1006 \pm 134 \mathrm{pmol} / \mathrm{l}$ increased the fraction of $\alpha$ PY-binding receptors, expressed as percentage of the total insulin receptors, from $0.4 \pm 0.1$ to $12 \pm 2 \%$ (Fig. 1A). This increase of the $\alpha$ PY-binding receptors was comparable in the patients' mother but lower in the patients' father. As, compared with the control subjects, the steady state insulin concentration during the clamp was more than twofold higher in the patients' father (2417 $\mathrm{pmol} / \mathrm{l})$, it can be estimated that the insulin effect to increase the $\alpha$ PY-binding fraction in the father's muscle was reduced by about $70 \%$ compared with the control subjects.

Kinase activities of the total, $\alpha P Y$-binding and non$\alpha P Y$-binding muscle insulin receptor fractions. The raised serum insulin concentrations in the control subjects increased the receptor kinase activity in the total insulin receptor fraction approximately sixfold (Fig.1B). This increase was comparable in the patient's mother. The patients' father had a smaller increase despite his more than twofold higher steadystate clamp insulin concentration. When the same receptors were activated in vitro by exposure to ATP and insulin before the kinase activity measurements, receptor kinase activities were about tenfold higher than those attained in situ at the clamp insulin concentrations (Fig.1E). The activities following in vitro-activation were similar in control subjects and in the patients' mother but $70 \%$ lower in the patients' father. The kinase activities of the $\alpha$ PY-binding insulin receptor fractions from in-situ-stimulated muscle biopsies were higher than those in the respective total fractions (Fig.1C). In contrast, the receptors in the non- $\alpha$ PY-binding fraction had low activity (Fig.1D), indicating that the binding to $\alpha \mathrm{PY}$ effec- 

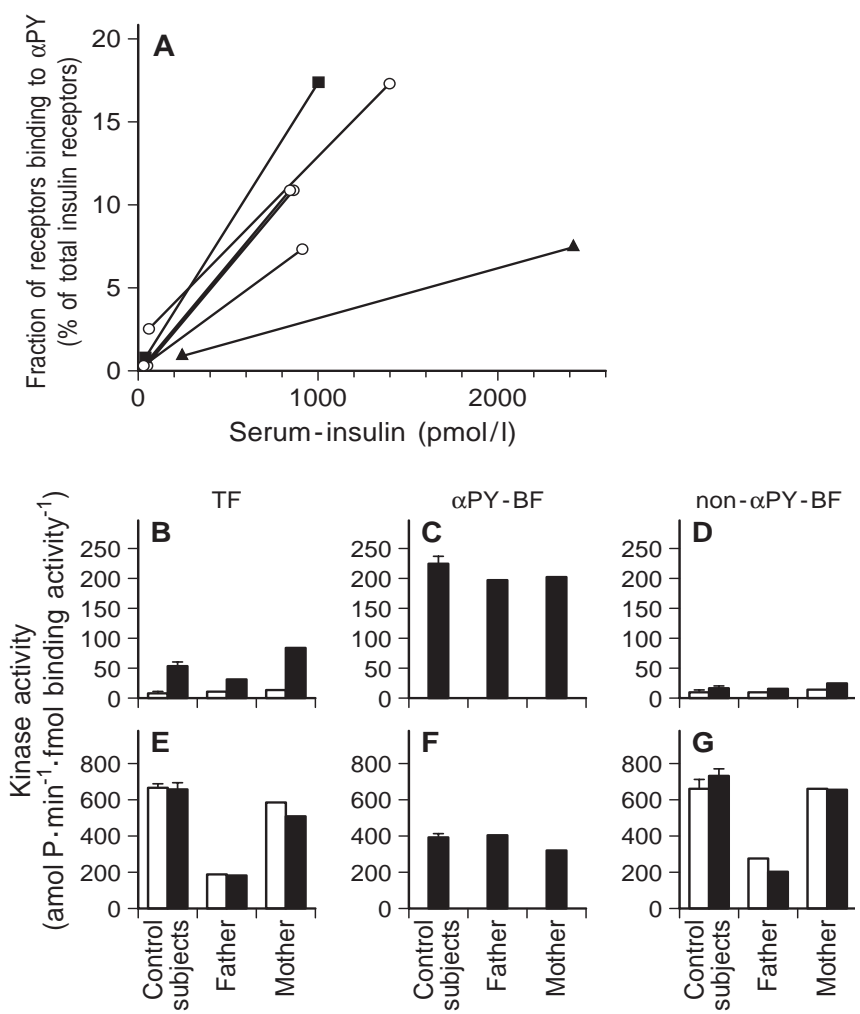

Fig. 1A-G. Effect of serum insulin concentration on the amount of $\alpha$ PY-binding muscle insulin receptors $(\mathbf{A})$ and on receptor kinase activities in the total, $\alpha \mathrm{PY}$-binding and non- $\alpha \mathrm{PY}$ binding insulin receptor fractions (B-G). Muscle biopsies were taken at the end of the basal and again at the end of the 4-h euglycaemic hyperinsulinaemic clamp period and solubilized. To separate $\alpha$ PY-binding and non- $\alpha$ PY-binding insulin receptor fractions, portions of the solubilized muscle samples were incubated in microwells coated with $\alpha \mathrm{PY}$. Bound and unbound proteins were then transferred to separate microwells coated with $\alpha \mathrm{IR}$ as described in the Methods section. In addition, other $\alpha$ IR-microwells were directly filled with a portion of the solubilized muscle samples (total insulin receptor fraction). After $16 \mathrm{~h}$, the $\alpha$ IR-microwells were washed and receptor kinase and binding activities measured without $(\mathbf{A}-\mathbf{D})$ or with prior in vitro-activation $(\mathbf{E}-\mathbf{G})$. A Insulin binding activity in $\alpha$ IR-microwells to which the $\alpha \mathrm{PY}$-binding protein fraction had been transferred, expressed as percentage of the binding activity in aIRmicrowells to which the solubilized samples had been added directly. Shown are the data from 4 nondiabetic control subjects $(\bigcirc$, means \pm SEM), the patients' father $(\boldsymbol{\Delta})$ and mother $(\square)$. B-G Kinase activities without (B-D) or with prior in vitro-activation $(\mathbf{E}-\mathbf{G})$. All data are shown as kinase activity per insulin binding activity and therefore reflect kinase activities per receptor. Shown are the data from the nondiabetic control subjects (means \pm SEM), the patients' father and mother. TF $(\mathbf{B}, \mathbf{E})$ : total fraction; $\alpha \mathrm{PY}-\mathrm{BF}(\mathbf{C}, \mathbf{F})$ : $\alpha \mathrm{PY}$-binding fraction; non$\alpha \mathrm{PY}-\mathrm{BF}(\mathbf{D}, \mathbf{G})$ : non- $\alpha \mathrm{PY}$-binding fraction $\square$ basal biopsy clamp biopsy

tively separated activated from non-activated receptors.

In contrast to the results in the total insulin receptor fraction, where the father's receptors displayed reduced in situ- and in vitro-activated kinase activity,

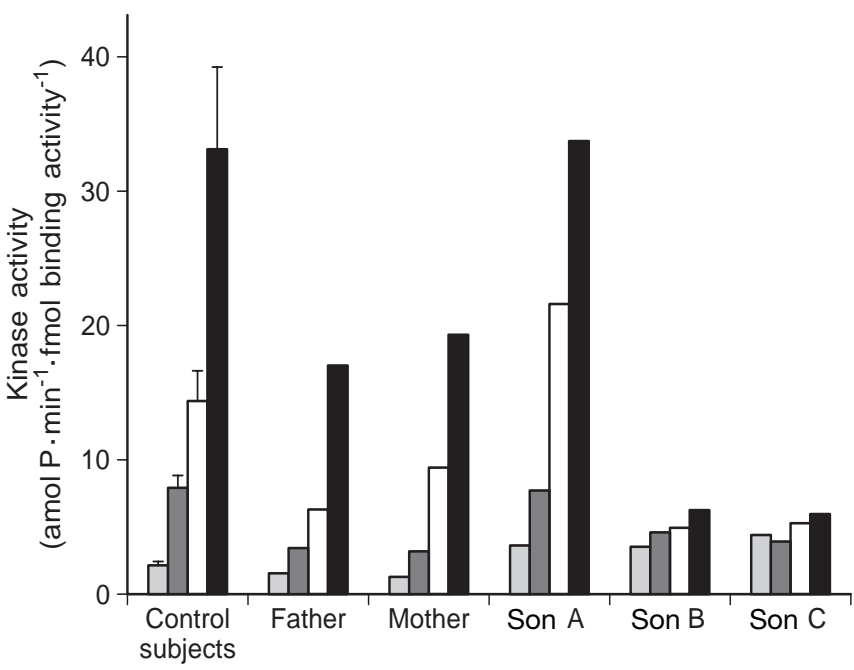

Fig. 2. Activation of insulin receptor kinase in erythrocytes from family members and control subjects. Blood was drawn from all family members and from control subjects and incubated with insulin $(\square: 0 \mathrm{nmol} / \mathrm{l}, \quad: 1 \mathrm{nmol} / \mathrm{l}, \square: 4 \mathrm{nmol} / \mathrm{l}$, and

: $400 \mathrm{nmol} / \mathrm{l}$ ) as described in the Methods section. The solubilized blood was then added to microwells coated with $\alpha$ IR, and after insulin receptor immobilization kinase reactions with recombinant IRS-1 were carried out. Kinase activities are normalized for insulin binding activities measured in the same wells. Results shown for the control subjects are means \pm SEM

such reductions were not observed in the $\alpha$ PY-binding fraction (Fig. 1 C, F). This suggests that this fraction of the father's muscle insulin receptors was functionally normal with respect to in situ and in vitro kinase activation.

Activation of insulin receptor kinase in erythrocytes. Since skeletal muscle was not available from the compound heterozygote sons, measurements of insulinactivation of insulin receptor kinase were also done in erythrocytes. In control subjects insulin incubation of these cells concentration-dependently increased insulin receptor kinase activity by about 15 -fold (Fig. 2). A similar increase was observed in the unaffected brother of the patients who carries no mutant allele (son A). Insulin stimulation of erythrocytes from the affected brothers (son B and $\mathrm{C}$ ) resulted in almost no increase in kinase activity (9.0 and 5.2\% compared with control subjects, respectively). The insulin effect on receptor kinase activity in the patients' mother and father was about $59 \%$ and $49 \%$, respectively, of that in the control subjects.

\section{Discussion}

Most current evidence suggests that insulin activation of the insulin receptor kinase requires two intact $\beta$ subunits [6]. Accordingly, heterozygosity for a single 
mutated allele would result in a ratio of $1: 3$ of functional to non-functional receptors [7]. Several factors might, however, cause deviations from this calculated ratio and might also result in tissue-specific variations. For example, the mutation could influence the processing of the gene product and its efficiency of oligomerization. Moreover, different properties of mutated receptors, like their lacking kinase activity and subsequent differences in their internalization, might lead to differential degradation rates.

To investigate the relative ratios of functional and non-functional insulin receptors present in skeletal muscle of the patients' parents, we took a novel approach. Insulin receptor kinase activities per receptor were not only evaluated in the total receptor fraction but also in receptor fractions that, after in-situ-stimulation, bound to anti-phosphotyrosine antibody or not ( $\alpha$ PY-BF and non- $\alpha$ PY-BF, respectively). Our results in the total receptor fraction from the father's muscle show that, compared with the muscle of control subjects, the effects of serum insulin to increase the fraction of tyrosine-phosphorylated receptors was reduced by about $70 \%$. In situ insulin-activation of the receptor kinase was also reduced by about $70 \%$ ([1]; Fig. 1), and a similar reduction of in vitroactivation was observed (Fig.1). Conversely, the kinase activity per receptor of the selected $\alpha \mathrm{PY}-\mathrm{BF}$ from the father's muscle was similar to that of the respective fraction in the control subjects, and this was the case both after in situ and in vitro activation (Fig.1). These findings therefore show that the selected receptors from the father's muscle that had been tyrosine-phosphorylated in situ had normal properties with respect to in situ and in vitro kinase activation. Moreover, these findings show that this receptor fraction contained no or few receptors that, due to the mutation of the receptor gene, might have had an intermediate or low kinase activity. Taken together with the observation that receptors that did not bind to $\alpha$ PY after in situ-stimulation had a low kinase activity (Fig.1), this suggests that the $70 \%$ reduction in kinase activity in the total fraction was caused by the inability of about $70 \%$ of the receptors to be insulin-dependently activated. This fits well with the calculated estimate of the ratio between functional and non-functional receptors of 1:3.

In the muscle of the patients' mother the effects of serum insulin to increase the fraction of tyrosinephosphorylated receptors and to activate the receptor kinase were similar to the control subjects. Moreover, in vitro-activation of these receptors was unaltered compared with control subjects. Taken together, these results indicate that only functionally intact receptors were present although mRNA for the 17splice variant was detected in transfected lymphocytes ([2]; Vorwerk P, personal communication). Our results thus fit well with the clinical data that show basal and insulin-stimulated glucose disposal rates comparable with the control group [1]. One potential explanation for the lack of non-functional (truncated) receptors in the mother's muscle could be a predominant transcription of the 17 + variant from the mutated allele. This appears, however, unlikely considering our results in the compound heterozygote sons. The kinase activity in their erythrocytes was only 5 and $9 \%$, respectively, of that in control subjects. This is much lower than the kinase activity in their father's erythrocytes $(49 \%$ of that in control subjects), suggesting that, at least in the sons, the transcription of the $17+$ variant from the allele with the splice site mutation is severely impaired. If one assumes a similarly impaired transcription of the 17 + variant from the mutated allele in the mother, the absence of non-functional receptors in her muscle suggests that most of the receptor protein in that tissue originates from the non-mutated allele. Potentially, the transcription of both splice variants is impaired. Alternatively it is possible that the 17-variant is predominantly transcribed but that the truncation of the receptor affects post-translational processing or results in faster degradation [8].

Although clearly no impairment of in situ and in vitro receptor kinase activation was observed in the mother's skeletal muscle, our erythrocyte data indicate that such an impairment could be present in these cells. Different relative abundancies of mutant and non-mutated receptors in different tissues could be caused by different receptor synthesis, processing or degradation or both. Moreover, different ratios of functional to non-functional insulin receptors in different tissues could also be caused by differences in insulin-like growth factor-1 (IGF-1) receptor expression leading to different IGF-1/insulin receptor hybrid formation. Data obtained in erythrocytes may therefore not exactly reflect the situation in muscle. Nevertheless the profound ( $\approx 90-95 \%$ ) impairment of receptor kinase activation in the erythrocytes from the compound heterozygous sons suggests a severe impairment also in their skeletal muscle. This fits well with their severe insulin resistance and the existence of at least some insulin-stimulable kinase activity (Fig. 2) could explain their phenotype which is different from other homozygous or compound heterozygous mutations of the insulin receptor gene associated with complete loss of kinase-active insulin receptors [1].

The $\operatorname{Arg}^{1174} \rightarrow$ Gln mutation has been described previously $[9,10]$. Consistent with our data, an approximate $70 \%$ reduction of in vitro insulin receptor kinase activity in Epstein-Barr virus-transformed lymphocytes of a patient with the mutation has been found [9]. A normal endogenous IRS-1 phosphorylation despite markedly decreased insulin receptor autophosphorylation in Chinese hamster ovary (CHO)cells overexpressing the mutation has also been reported [10]. This is in contrast to our data that show a 
clear reduction of the in vitro-phosphorylation of GLU4:TYR1 and recombinant IRS-1, but it is possible that in that system receptors were vastly overexpressed which compensated for a low kinase activity.

In summary we have shown that the $\operatorname{Arg}^{1174} \rightarrow$ Gln insulin receptor mutation in its heterozygous state leads to an approximate $70 \%$ reduction in receptor kinase activation in intact skeletal muscle. This is due to the fact that about $70 \%$ of the receptors have a severely impaired or missing ability to be insulindependently activated. In the presence of a non-mutated allele, the $\mathrm{G}$ to A change in position 3396 in one allele of the insulin receptor gene does not lead to the presence of a detectable number of receptors with impaired kinase function in skeletal muscle. In the compound heterozygote state with the $\mathrm{Arg}^{1174} \rightarrow$ Gln mutation it results, however, in a severe impairment of insulin receptor function and severe insulin resistance.

Acknowledgements. This work was supported by grants from the Deutsche Forschungsgemeinschaft (H.H. Klein, K1503/ 7-3), the European Union (H.H. Klein, BMH4-CT960751; O. Pedersen, BMH4-CT950662), the Danish Medical Research Council (O. Pedersen), the Poul and Erna Sehested Hansens Foundation, and the Jacob Madsens and Olga Madsens Foundation (H. Vestergaard). The expert technical assistance by M. Drenckhan is kindly appreciated.

\section{References}

1. Vestergaard H, Klein HH, Hansen Tet al. (1995) Severe insulin-resistant diabetes mellitus in patients with congenital muscle fiber type disproportion myopathy. J Clin Invest 95: 1925-1932

2. Vorwerk P, Vestergaard H, Christoffersen CT, DeMeyts P, Pedersen O (1994) Insulin receptor mutations in a novel syndrome of insulin resistance. Diabetologia 37:A29 (Abstract)

3. Klein HH, Vestergaard H, Kotzke G, Pedersen O (1995) Elevation of serum insulin concentration during euglycemic hyperinsulinemic clamp studies leads to similar activation of insulin receptor kinase in skeletal muscle of subjects with and without NIDDM. Diabetes 44: 1310-1317

4. Klein HH, Kowalewski B, Drenckhan M, Fehm HL (1997) Insulin stimulation of human adipocytes activates the kinase of only a fraction of the insulin receptors. Am J Physiol 272:E576-E583

5. Klein HH, Kowalewski B, Drenckhan M, Neugebauer S, Matthaei S, Kotzke G (1993) A microtiter well assay system to measure insulin activation of insulin receptor kinase in intact human mononuclear cells. Decreased insulin effect in cells from patients with NIDDM. Diabetes 42: 883-890

6. Frattali AL, Pessin JE (1993) Relationship between alpha subunit ligand occupancy and beta subunit autophosphorylation in insulin/insulin-like growth factor-1 hybrid receptors. J Biol Chem 268: 7393-7400

7. Taylor SI, Accili D (1996) Mutations in the genes encoding the insulin receptor and insulin receptor substrate-1. In: LeRoith D, Taylor SI, Olefsky JM (eds) Diabetes mellitus. Lippincott-Raven, Philadelphia, pp 575-583

8. Levy-Toledano R, Accili D, Taylor SI (1993) Deletion of Cterminal 113 amino acids impairs processing and internalization of human insulin receptor: comparison of receptors expressed in $\mathrm{CHO}$ and NIH-3T3 cells. Biochim Biophys Acta 1220: 1-14

9. Moritz W, Froesch ER, Boni-Schnetzler M (1994) Functional properties of a heterozygous mutation $\left(\mathrm{Arg}^{1174} \rightarrow \mathrm{Gln}\right)$ in the tyrosine kinase domain of the insulin receptor from a type $\mathrm{A}$ insulin resistant patient. FEBS Lett 351: 276-280

10. Krook A, Moller DE, Dib K, O'Rahilly S (1996) Two naturally occurring mutant insulin receptors phosphorylate insulin receptor substrate-1 (IRS-1) but fail to mediate the biological effects of insulin. Evidence that IRS-1 phosphorylation is not sufficient for normal insulin action. $\mathbf{J}$ Biol Chem 271: 7134-7140 